\title{
In a Sacred Manner We Died: Native American Near-Death Experiences
}

\author{
Jenny Wade, Ph.D. \\ Institute of Transpersonal Psychology
}

\begin{abstract}
This article presents 11 historical Native American near-death experiences from the $1600 \mathrm{~s}$ to the early $20^{\text {th }}$ century as they appeared in the accounts of early explorers, autobiographical records, and ethnographic accounts. It includes two stories from tribes around the Roanoke, Virginia area; two Chippewa accounts from the Mississippi Valley; a Chiricahua Apache account reported by Geronimo; two Zuni reports; two Saulteaux accounts from the Berens River area of what is now British Columbia; and two stories from the Oglala Sioux Black Elk. I explore commonalities among the accounts and comparisons with near-death experiences from other cultures.
\end{abstract}

KEY WORDS: near-death experience; Native Americans.

This article represents the first overview of historic Native American accounts of near-death experiences. It was begun when Harry Miller of Bowling Green, KY, drew my attention to two accounts he had come across through an antiquarian book dealer who possessed some of the original folio pages of the 1623 edition of Captain John Smith's Generall Historie, and although this paper does not aspire to a complete investigation of all the Native American records, it presents at least a representative sample of historical accounts precluding, as much as possible, colonial influences.

Jenny Wade, Ph.D., is a developmental psychologist specializing in consciousness studies, especially consciousness at the edges of life, and adventitious altered states occurring in normal populations. She is on the core faculty at the Institute of Transpersonal Psychology and on the adjunct faculty at the Santa Barbara Graduate Institute, the Saybrook Institute, and John F. Kennedy University. Reprint requests should be address to Dr. Wade at 235 Uplands Circle, Corte Madera, CA 94925; e-mail: jwadephd@yahoo.com. 
It is difficult, if not impossible and inappropriate, to bring the usual standards for today's field studies to bear on accounts from ancient indigenous cultures that suffered unknowable colonial contamination, when they were not utterly destroyed; that had largely oral traditions in languages their recorders often did not speak; that had spiritual traditions that might have been concealed from all outsiders, especially their conquerors; and that did not recognize arbitrary categories like "fact" and "myth," especially in regard to spiritual matters. "Spiritual matters" in themselves often do not constitute a separate category from "secular" matters in most indigenous and traditional cultures; concepts like "spiritual" and "secular" are rather modern Western constructions. Therefore some important qualifications should be borne in mind regarding the presentation of these narratives.

They represent diverse First Nations cultures from different geographic areas and times, recorded by Europeans or EuroAmericans with varying degrees of skill and varying relationships to their sources. Although the stories are grouped by culture, the primary organization is from the earliest to the latest records, in an attempt to order them from when European incursions were minimal up to the point where the Native Americans had, in their turn, become the minority culture. This may not seem, on the surface, to make much difference, since the stories themselves are quite diverse across tribal groups. However, the influence of the colonials can be traced in some of the stories, in the questions and expectations some narrators were addressing, and certainly in the way the accounts were obtained. The power balance between narrator and recorder shifted as European or EuroAmerican recorders went from being guests hospitably treated or merely tolerated to being the conquerors of an eviscerated, endangered remnant, who treated the people they were studying like a raree-show, often too arrogant even to learn their language. Compounding that, of course, is the fact that many of the reports were gathered by ignorant colonials who represented the cultural biases of their day and whose judgments probably distorted the meanings entrusted to them as much as language differences did.

In cultures where oral transmission is primary, many members have unusually well-trained memories for the spoken word, and provide almost word-for-word accounts of material that has been passed across numerous speakers over time and distance; the congruence of ancient Norse oral traditions from widely dispersed geographic areas over centuries is a prime example. Nevertheless, it is difficult to generalize about such diverse groups as those represented 
by the North American First Nations people. Thus the exact choice of words may well have been significant, such as indicating which narratives represented shamanic soul-journeying and which represented "real" near-death experiences (NDEs); but many such distinctions may have been lost forever, owing to poor translation or the tendency of the European recorders to dismiss Native American accounts as the fantasies and myths of quaint "ignorant savages."

Ironically, some of the more recent EuroAmerican enthusiasm for indigenous spiritual traditions has led to a greater conflation of NDEs with other otherworldly adventures, rather than a clarification. Although commonalties between NDEs and shamanic journeying have been widely noted (Green, 1998, 2001; Kalweit, 1988; Ring, 1992), they are often grouped willy-nilly with other otherworldly altered states (Kalweit, 1988, Schorer, 1985). Without specific language suggesting the individual was actually near death, it is often difficult to discern which narratives might actually represent NDEs, as opposed to other altered states in which a person journeys to a spirit world or underworld, including even cases of illness or injury where delirium or psychotropic medicaments may be factors, and where the nature of the conditions is obscure. The degree to which cultural elements or deliberate obfuscation may further confuse foreign ethnographers is hard to discern.

To try to bring as much clarity as possible to these confusing dynamics, I present all the following accounts with relevant context about the narrators, their beliefs about death and the afterlife, the events surrounding the episode, and the recorders. I made every attempt to include only stories that were attributed to historical people who were believed to have died from wounds or illness but recovered. Although some records were so long they had to be paraphrased, where possible they are given word for word. I will discuss the experiences after introducing all of the accounts.

\section{The Earliest Native American Near-Death Accounts}

Captain John Smith, "Sometime Governour of Virginia and Admirall of New England," as he styled himself in his Generall Historie of Virginia, the Somer Isles, and New England with the Names of the Adventurers and their Adventures, published in 1623, just 16 years after the establishment of Jamestown, chronicled what would appear to be the first recorded NDEs in the New World. The 
Generall Historie is an anthology comprising six books on the first English-settled areas of the New World. Book I is Smith's haphazardly compiled extracts from "ancient authors" (as early as 1584) dealing with the discovery, exploration, and history of America, as well as his own first-person accounts. His reports of NDEs may well be the most significant of the Native American records for two reasons. First, they represent actual, recent events (regrettably not witnessed by Smith), rather than ancient oral traditions that might have acquired mythic or instructional cultural overlays. And second, they occurred well before Christian proselytizing had had much impact on the First Nations' traditional beliefs. I present Smith's report in its entirety:

They beleeve the immortalitie of the Soule, when life departing from the body, according to the good or bad workes it hath done, it is carried up to the Tabernacles of the gods, to perpetuall happinesse, or to Popogusso, a great pit: which they thinke to be at the furthest parts of the world, where the Sunne sets, and there burne continually.

To confirme this they told me of two men that had beene lately dead, and revived againe; the one hapned but few yeares before our coming into the country; of a bad man, which being dead and buried, the next day the earth over him being seene to move, was taken up, who told them his soule was very neare entering into Popogusso, had not one of the gods saved him and gave him leave to returne again, to teach his friends what they should doe to avoyd such torment. The other hapned the same yeare we were there, but sixtie myles from us, which they told me for news, that one being dead, buried, and taken up as the first, shewed, that although his body had layne dead in the grave, yet his soule lived, and had travailed far in a long broad way, on both sides whereof grew more sweet, fayre, and delicate trees and fruits, then ever he had seene before; at length he came to the most brave [fine] and fayre houses, neare which he met his Father, that was dead long agoe, who gave him charge to goe backe, to shew his friends what good there was to doe, to injoy the pleasures of that place; which when hee had done hee should come againe. (Smith, 1623, Book I, folio 11, in Barbour, 1983, p. 79).

\section{Two Chippewa Tales}

Two centuries later, in the 1820 s, a scout named Henry Schoolcraft was commissioned by the United States government to explore the Mississippi Valley with regard to its mineral resources. His lengthy report was published (Schoolcraft, 1975/1825) for wider distribution, in part because of the interest it provoked about these relatively unknown territories and the "aboriginal populations" who lived there. 
Although Schoolcraft's narrative contained the blatantly chauvinistic distortions characteristic of EuroAmerican colonial attitudes at the time and he frequently made undifferentiated generalizations when he might actually be talking about such diverse groups as the Iroquois, Wyandots, Senecas, Ricaras, Chippewas, and so on, he was perhaps still close enough to the Romantic period and some of its Noble Savage ideals to recognize and admire many Native American values, practices, and characteristics. He was also a great appreciator of their language and its complexity.

In one of his generalities, Schoolcraft observed that Native Americans were "deists" who did not fear death but regarded it as a change of state that ends a life of both earthly pleasures and hardships, with the emphasis on the diminishment of suffering at death, although some notion of reward and punishment existed (Schoolcraft, 1975/1825). Strong beliefs about the nature of the afterlife appear to have been inchoate:

But what this happiness is to be, where it is to be enjoyed, and what is to be the nature of the rewards and punishments, does not appear to be definitely fixed in the minds of any. If a man dies, it is said, he has gone to the happy land before us-he has outrun us in the race, but we shall soon follow. (Schoolcraft, 1975/1825, p. 397)

The dead were dressed in their best clothing, and a close relative or elder addressed the deceased as if he or she were still conscious of what was taking place (Schoolcraft, 1975/1825). They were told what to expect in the afterlife, and reminded of their preparation for the trials they would undergo, as Schoolcraft reported from personally witnessing some funerary preparations:

You are going to go to another country, which we trust you will find pleasant; but in your journey thither, you will have to be very cautious how you travel, for your path is beset with dangers. There is one place in particular, where you must be extremely cautious. You have a dark stream to cross, which is wide and deep, and the water runs rapidly. There is but a single tree lying across it, and you will be compelled to cross over it, without the help of a staff ...

If your actions have been pleasing to the Great Spirit ... you will get safely over; but if not, you will surely fall into the stream. (1975/ 1825, p. 398)

The theme of this perilous passage over a narrow bridge appeared here and elsewhere in beliefs about the afterlife (Thompson, 1929; it also appeared in other cultures, as reported by Zaleski, 1987), but interestingly it was never mentioned as transpiring in any of the accounts. The general practice Schoolcraft reported (1975/1825) was 
for the orator then to describe actual events when he killed and scalped an enemy warrior, whose spirit then became enslaved to him. The orator ceremonially transferred ownership to the deceased, who would then encounter the slave after death and would have to ask him to serve him by hunting to provide food for the journey, cutting wood and making fires, and otherwise ensuring the deceased's comfort after death. Weapons, cooking vessels, and provisions were placed around the deceased for the slave to use in carrying out these tasks. A dog was sometimes dispatched to accompany the dead.

After describing the custom of building a small fire on the grave for four or more nights after a funeral he had witnessed, Schoolcraft proceeded to tell of an altered-state event associated with death (1975/ 1825). He alleged that he recorded an almost word-for-word account, which I have paraphrased here for length constraints, told to him by Chippewas at the Sault of St. Mary, in what is now Michigan. He added that his account represented a faithful English translation of what was said, free from the conventional literary embellishments valued by EuroAmericans at the time because he was too rushed in taking notes, and then later declined to change the almost word-for-word record (Schoolcraft, 1975/1825, p. 409). In fact, he expressed regret that no English translation could capture the beauty and poetry of the original.

It is notable that this story was not attributed to a named individual, for it, and the following account, which was ascribed to a chief from the vague past, seem markedly different from the other NDEs. According to this oral history (Schoolcraft, 1825/1975, pp. 404-409), a small Chippewa war-party fought a fierce battle with their enemies, and just as their leader had secured the victory, he was shot in the chest with an arrow and fell dead. The custom was not to bury warriors who died in battle. His body was arrayed in his headdress and other accoutrements, and his bow was leaned against his shoulder as he was propped in a sitting position with his back against a tree, in a position to gaze in the direction of the fleeing enemies.

Evidently the leader was not dead, however, for though he could neither move nor speak, he later said he heard all his friends had said, and felt their hands arranging his body. He was consumed with a desire to remain with them, and as they departed for home, he made a mighty exertion and seemed to rise and follow their tracks. However, after repeated anguished attempts to get their attention, he realized that they could not see him. Frustrated, angry, and disappointed, he nevertheless kept pace with them on the long journey. His bodily needs had not ceased, but he was unable, of course, to eat or drink, and his wounds 
bothered him. The only thing he could do was sleep when they slept. He berated them for not helping him, but "no one seemed to hear his words; if they heard his voice they mistook its sound for the winds of summer, rustling among the green leaves" (Schoolcraft, 1975/1825, p. 406).

The war party finally arrived at their village, where they sang the praises of the fallen leader's bravery to the man's elderly father and his wife. The more the stories were told, the more indignant the dead leader became, insisting that he had not been killed and left upon the battlefield, but was right in their midst. He followed his wife into their lodge and watched her grieve and lament. Shouting as loudly as he could, he demanded that she tend his wounds and bring him food, but she merely remarked to someone sitting near that she heard a buzzing in her ear. The husband, enraged, struck her as hard as he could on the forehead, but she merely touched her forehead saying she must have a slight headache.

At this point, the warrior seemed to recollect traditions he had learned in which the spirit could leave the body, and it began to dawn on him that perhaps only his spirit had accompanied his friends and that his body indeed might still be on the battlefield, four days' journey away. He immediately began the return journey, which was uneventful until the evening of the fourth day, when he approached the edge of the battlefield. A fire then appeared on the path in front of him, and no matter which way he moved, it moved with him to block his passage. He declared his lack of fear and jumped through it. When he did so, he awoke from his eight-day coma, finding himself just as his friends had left him. Up in the tree they had propped him against was a "canieu or war eagle" (Schoolcraft, 1825/1975, p. 408), the bird he had selected as his guardian spirit in youth, which he believed had kept watch over his body and kept scavengers away. He got up, but was very weak. His wound was no longer bleeding, so he bound it and prepared and ate medicinal plants he foraged to recover his strength. There was no big game nearby, though, and he was exceedingly hungry. Sustaining himself by shooting small birds, he journeyed back to his village, greatly surprising everyone.

The war leader then related his adventures to his people and told them that it would please the deceased to have a fire built upon his grave for four nights after death, for the light and warmth it would provide on the four-day journey "to the land appointed for the residence of the spirit" (Schoolcraft, 1975/1825, p. 409), and so that the spirit would not be subjected to this irksome task.

Schoolcraft followed this story with a brief commentary about changes 
in burial customs among the Chippewa (1975/1825, p. 410). Formerly they had buried almost everything a person owned with the deceased, but they later limited grave goods to a few favorite articles. Schoolcraft attributed this change to a story about Gitshee Gauzinee, an allegedly historic chief "of former days" (1975/1825, p. 410).

Gitshee Gauzinee died suddenly after an illness of a few days. A renowned hunter, he had requested that his rifle be buried with him, but nobody wanted to do this, since guns had only recently been introduced to the Chippewas and were extremely precious. Some people, believing he might not be dead but comatose, determined not to bury him right away, but to remove his body to a separate lodge where it was carefully attended by his widow, who, at times, thought she could detect a feeble heartbeat. In four days, Gitshee Gauzinee awoke, complaining of thirst, and then began to regain his strength. He related how he had traveled uneventfully for three days "on the path of the dead" (Schoolcraft, 1975/1825, p. 411). He was getting hungrier and hungrier, and on the fourth day, when he came within sight of the "village of the dead," he saw lots of healthy, fat game, including herds of deer and moose, who grazed tamely near his path. He could do nothing to assuage his hunger, however, because he had no weapons. He remembered the gun he had left behind and began the return journey to get it.

On the way back, he met hordes of heavily laden men, women, and children traveling toward the village of the dead. They were all complaining about being burdened by having to carry their axes, kettles, pots, pans, clothing, food, and so on, that their friends had given them at their deaths. Gitshee Gauzinee courteously listened to their complaints and accepted as gifts some of the items offered to him to lighten the loads of others, but he continued on his way back to his lodge. Here, he was barred from entering by a wall of fire that encircled the lodge and would flame up into "brilliant cones" wherever he attempted to cross. He finally made one desperate attempt to cross it, which brought him back to life. He advised his friends that their ancient habits were burdensome to the dead, and that from that point on they should dress the dead in their best clothes to delight them and only bury things that could be carried easily, with perhaps a pipe to "afford ... a pleasant amusement on [the] road. If he has anything more, let it be divided among his nearest relatives and friends" (Schoolcraft, 1975/1825, p. 412).

These stories may or may not recount actual events that were mythologized later. Schoolcraft did not demonstrate any awareness 
of NDEs, which conceivably might have been rare but certainly not unheard of at that time, regardless of how they were framed: "It will be at once perceived that their traditions and fictions are intimately blended. It would be impossible to decide whether the custom existed prior to the tale, or the tale has been invented to suit the custom" (1975/ 1925, p. 404). Schoolcraft made it clear (1975/1825, p. 412) that he viewed these two narratives as tutelary tales whose purpose was primarily to maintain custom and instruct the young in the proper traditions.

Despite the reporter's thoughtful qualification, 160 years later, in a 1985 issue of Omega, C. E. Schorer, a physician at Wayne State University, published a paper on Schoolcraft's Chippewa accounts, stating that they "exemplify two types of near-death experiences." Schorer's article was rather garbled; he first suggested that the two accounts were NDEs, citing as proof the "autoscopic" nature of the first and the "transcendental" elements of the second, as Michael Sabom (1982) had used those terms to categorize NDEs (Schorer, 1985, p. 111). But then Schorer itemized elements that were actually not part of these narratives but either appeared in later parts of Schoolcraft's report or in other sources, including two poems that he alleged "are certainly in the form of popular nineteenth-century American gift books," in an attempt to "argu[e] for the influence of the white man" on these stories (1985, p. 112). Both his mixing of sources and his reasoning are obscure, especially since he promiscuously cited Stith Thompson's Tales of the North American Indians as containing similar accounts ("many tales of Native American travel through the land of the dead" [Schorer, 1985, p. 112]). In fact, this book is a compendium of myths and folktales, none of which was represented as having any historical basis, nor of having any stronger relationship to the afterlife than the enchanted realms of European folktales, where heroes are tempted by visions of plenty and are compelled to undergo trials. Schorer's efforts obfuscated rather than clarified the potential of Schoolcraft's contribution, a trend seen in other compilations.

\section{Geronimo's Account}

In an autobiography recorded and published by Stephen Melvil Barrett in 1906, the great Chiricahua Apache chief Geronimo (18291909) spoke about his people's rather vague beliefs about survival of death and the afterlife. He sounded personally skeptical about survival, especially as it was expressed by Christians: 
As to that future state, the teachings of our tribe were not specific, that is we had no definite idea of our relations and surroundings in the after life. We believed that there is a life after this one, but no one ever told me as to what part of man lived after death. I have seen many men die; I have seen many human bodies decayed, but I have never seen that part which is called a spirit; I do not know what it is; nor have I yet been able to understand that part of the Christian religion.

We held that the discharge of one's duty would make his future life more pleasant, but whether that future life was worse than this life or better, we did not know, and no one was able to tell us. We hoped that in the future life family and tribal relations would be resumed. In a way we believed in this, but we did not know it. (Barrett, 1970/1906, pp. 166-7)

It must be remembered that Geronimo, who had held out the longest against the United States government, and escaped imprisonment only to be dragged back to the United States from Mexico as a prisoner of war when he was already an old man, was regarded by his people as having the magical powers associated with shamans. By the time this narrative was recorded, his people had been virtually destroyed and their nation was rapidly being industrialized. He was ending his days in captivity in the occupied territory of the murderers of his family and his world. He had formally joined the Dutch Reformed Church; he was baptized in the summer of 1903 and attended services regularly during his incarceration at the Fort Sill Reservation, but was ultimately expelled for gambling (Barrett, 1970/1906, p. 169). It is undoubtedly significant that in discussing the following near-death story, he prefaced and ended his remarks with qualifications strongly suggesting that his conversion was a pragmatic concession to his hopeless circumstances:

Since my life as a prisoner has begun, I have heard the teachings of the white man's religion, and in many respects believe it to be better than the religion of my fathers. However, I have always prayed, and I believe that the Almighty has always protected me.

Believing that in a wise way it is good to go to church ... I have advised all of my people who are not Christians, to study that religion. (Barrett, 1970/1906, pp. 168-169)

Geronimo related a story told to him by an unnamed tribesman he met when both were forced to live on the San Carlos Reservation. This man claimed that while lying unconscious on a battlefield, he had died and passed into the "spirit land" (Barrett, 1970/1906, pp. 167-168). He first came to a place where a mulberry tree was growing out from 
a cave in the ground. A guard seemed to be posted in front of the cave, but the guard let him pass unchallenged when approached without showing any fear. The path into the cave descended, and after a little way it widened, terminating in a huge, perpendicular rock that stretched for hundreds of feet in all directions. Although it was dark, by peering around, the man was able to grasp a bush and swing himself from the edge of the rock, so that he could drop into a pile of sand that started about twenty feet down, which allowed him to slide quickly down the steep rock into the blackness.

He found himself in a narrow passage at the bottom that led westward, through a canyon that became progressively lighter until it was as bright as day, though no sun could be seen. The passage became extremely narrow at a point where two gigantic snakes coiled. As he approached, they reared and hissed at him, but when he showed no fear, they also let him pass. Then the passage widened, and there, two grizzly bears started to attack him, but when he spoke calmly to them, they too gave him ingress. At a later, wide part of the passage, two mountain lions threatened him, but let him pass unchallenged when he spoke to them with courage. After this, the passage narrowed again and its walls were "clashing together at regular intervals with tremendous sounds" (Barrett, $1970 / 1906$, p. 168). When he approached, though, they remained apart until after he had safely passed. He then found himself in a forest, where he followed a westward path until he came to a "green valley where there were many Indians camped and plenty of game" (Barrett, 1970/1906, p. 168) and where he recognized many people he had known during life. This place was so pleasant, he was sorry to be brought back to consciousness.

Geronimo's reaction to this narrative was measured:

I told him if I knew this to be true I would not want to live another day, but by some means, if by my own hands, I would die in order to enjoy these pleasures. I myself have lain unconscious on the battlefield, and while in that condition have had some strange thoughts or experiences; but they are very dim and I cannot recall them well enough to relate them. Many Indians believed this warrior, and I cannot say he did not tell the truth. I wish I knew that what he said is beyond question true. (Barrett, 1970/1906, p.168)

Frederick Turner, the editor of the 1970 edition of Barrett's account, added this footnote, five years before Raymond Moody (1975) coined the term "near-death experiences": "This dream vision was a standard one among the Chiricahua and serves to remind us of the various and 
profound ways in which a culture influences the minds of its people" (Turner, in Barrett, 1970/1906, p. 168).

\section{Two Zuni Stories}

Death and the afterlife are two areas of relatively minimal religious significance in Zuni spirituality, which is focused on religious ritual and ceremony to promote fertility through rain and which has a communal rather than an individual focus (Benedict, 1934; Hultkrantz, 1987). The rituals associated with death, like those associated with marriage, are the least complicated, take very little preparation, and are finished as quickly as possible so the community's life can go on. The few myths that refer to the spirit land where the dead go are vague. Similar to most other Native American traditions, the dead do not depart for the underworld for four days, and when they go, they take a westward path. They have ghostly bodies that are invisible and that permit them to pass through objects unharmed, but they wear a feather on their heads that may be seen. They take the form of the wind, and can change shape at will. They can penetrate the lake of the kachinas, which the living are unable to do. It is not healthy for the living to grieve long for them or make changes in their lives that would offend the dead, such as a widower taking a new spouse, for they fear that the dead would be drawn to their grief or angered by their actions and would come to harm them or snatch them away into death. None of these elements appears at all in the NDEs reported.

In Holger Kalweit's classic book on shamanism, Dreamtime and Inner Space (1988), he reported a story collected by prominent anthropologist Ruth Bunzel who studied Zuni culture in the early $20^{\text {th }}$ century. Unfortunately, Kalweit's full citation of Bunzel's work is missing, but he appeared to be referencing The Forty-Seventh Report of the Bureau of American Ethnology 1920-1930 published by the Smithsonian Institute. Kalweit was knowledgeable about NDEs and he speculated on their relationship to nonvolitional shamanic initiations and other forms of shamanic journeying, though without suggesting that the two are interchangeable. He provided this direct quote of a story a Zuni told Bunzel:

When I was sick [with] the measles I was very sick. On the third day I didn't know anything. Maybe I fainted, or maybe I really died and came back. I never believed that could happen, but it really did, 
because when I came back the room was going round and round and there was a little light coming through the window, although there was a bright light in the room. While I was dead I dreamed I was going toward the West. ... I was so happy to see my grandfather. Since then I've never worried about dying, even when I was very sick, because I saw all these dead people and saw they were still living the way we do. (Bunzel, cited in Kalweit, 1988, p. 204; ellipses in Kalweit)

Kalweit (1988) went on to state, however, that Native Americans expected experiences of the light and that these were not necessarily limited to NDEs but could occur in other states where the soul was the primary perceiver rather than the sensory organs:

Light-experiences are very common when a person comes close to death. Tribal societies commonly believe that the inner light is not perceived by the physical body, but by the soul-body in an altered state of consciousness [dying or a shamanic state]. Sometimes the soul itself is considered to be the body of light. (Kalweit, 1988, p. 204)

It is notable that in one of the accounts below, Black Elk, after returning from an otherworldly journey while seriously ill but that was not specifically identified as the place of the dead, appeared to certain others to be filled with light.

Kalweit reported another Zuni account told to anthropologist Frank Hamilton Cushing in 1882 by his adoptive father and governor of the Zuni, Palowahtiva (Cushing, cited in Kalweit, 1988, pp. 39-41). When he was a young man, Palowahtiva was critically ill and had been too weak to get out of bed for days. His relatives had been summoned but had not yet arrived. Even though it was daylight, his vision darkened:

Then I saw again, and the light was coming through the window at the end of the room, brighter than before, so that all things were clear to me, very clear. I looked around the room, wondering that everything was so much better than it had been for so long ... feeling that I no longer need lie there.

I saw a broad-shouldered, god-sized man coming toward me. ... I did not know him. He was dressed in the ancient costume of my people. He came toward me, holding in one hand, which was extended toward the door a [lasso], as though he had led a horse behind him. (Kalweit, 1988, p. 39)

The man looked down at Palowahtiva lying there, smiled, but instead of expressing the customary greetings, uttered a single word 
that is usually translated as meaning "is everything ready?" (Cushing, cited in Kalweit, 1988, p. 39). Palowahtiva assented but hesitated, because he did not seem to know the man and could not see his face clearly against the bright light. The man explained that he was the sick man's "grand-grand-uncle" who had gone "away from the Zuni" "before you were in the womb of your mother" (Cushing, cited in Kalweit, 1988, p. 39-40). At this, Palowahtiva said he was ready, and the man said he had brought two fine horses, all saddled and bridled for the journey.

Palowahtiva was rising easily from his sickbed when a wrinkled, little old man "dressed in the most ancient costume" of the Zunis and with his hair done in a "strange old-fashioned knot" appeared in the room as though he had walked through one of the walls (Kalweit, 1988 , p. 40). Despite his ancient appearance and great age, he moved gracefully and majestically. The old man told the uncle that it was not time for Palowahtiva to go, but the uncle disputed with him. Their conflict was loving but decisive; the old man prevailed, and the uncle left through the door. The old man then turned toward Palowahtiva as he lay there and told him it was not his time:

One sometimes learns wisdom through great illness. Therefore you have been ill. ... You will not go, no. ... You will become old, even as I am, before you go.... Were you to go now, one fewer would be those in the world where so many once dwelt who give us those attentions which we cherish, who sacrifice plumes of worship to us, as was directed in ancient times, who pray to us and greet us, and show that our children among men have not forgotten us. ... Live, my child! .. . A few days, and your flesh will begin to gather upon your bones, and as you were, so will you become again. And although it may not be pleasant to you to think that you must endure illness and suffering, and many unhappinesses, yet know it is best that this should be so.... When the time has come for you to go, it will be said, 'Yes,' and we will come for you. Farewell. Be it even as I have said. (Cushing, cited in Kalweit, 1988, pp. 40-41)

The old man turned away, and Palowahtiva's vision grew dark again, and the next thing he knew, he heard the lamentations of his relatives who were chafing his hands and feet because they thought he had died (Cushing, cited in Kalweit, 1988, p. 41).

Both these stories are remarkable in that they do not correspond closely at all to traditional Zuni beliefs, as delineated above. 


\section{Two Reports from the Berens River Saulteaux}

The Saulteaux are a First Nations people located in what is now British Columbia. Aspects of their cultural approach toward death and dying were collected by Irving Hallowell and first published in the Journal of the Royal Anthropological Institute in 1940. Hallowell began his treatment with what at the time must have been a remarkable stance and one that is a tribute to his objectivity in field research:

Aboriginal beliefs in the reality of a life beyond the grave cannot be viewed as simple dogmas that gain currency without any appeal to observation and experience.

In the case of the Berens River Saulteaux, they are supported by the testimony of individuals who are said to have traveled beyond the bourne and returned to tell their fellows about it; by the testimony of those who have approached the land of the dead in dreams; by the resurrection, or resuscitation, of persons reputed to be dead; by the invocation of the spirits of the dead in the conjuring lodge, and in other ways. (1967/1940, p. 151).

Hallowell went on to say that, despite the fact that in "native theory" (not exclusively Saulteaux) the soul may detach from the body and travel to otherworldly realms in what are considered "real' experiences," the Saulteaux made clear, consistent linguistic distinctions to differentiate people who had actually visited the "spirit (ghost) land, [who] are usually persons believed to be dead, or thought to be fatally ill" from healthy people who had "dreamed" of these realms or entered them through other altered states but were healthy (1967/1940, p. 151). Although Hallowell acknowledged that this might have seemed farfetched to the EuroAmerican way of thinking, he honored the validity of the Saulteaux distinction:

The experiences described by persons observed to be dead, or fatally ill, are not said to have been "dreamed," while the "experiences" described by healthy persons are said to have been dreamed. The distinction is based on the direct observation of the bodily condition of the persons involved. In the former cases, it is coma, or illness, that lends support to their testimony. So far as I understand the matter, while healthy persons may dream of the dead, or even approach [the spirit or ghost land], their souls do not ordinarily visit this land of the dead. To do so is very dangerous, if one wishes to return to the land of the living; so only persons with extraordinary spiritual powers could achieve the journey ....

Specific individuals are referred to, whose historicity is not in question, however one may choose to evaluate their testimony. When I made inquiries about life after death, it was the alleged experiences 
of these individuals that were first mentioned. I was not given generalized statements. (1967/1940, pp. 151-2; emphasis in original)

As a result of these important distinctions captured by the narrators and the EuroAmerican recorder, there is more reason to believe these experiences represent NDEs rather than other altered-state journeying. Hallowell then presented two such narratives. The first one was told by a man who had heard it often related by an individual named Nabagábek (Flat-Stone) in the following manner:

I saw a man who died and lay dead for two days. He told me what had happened to him. He never felt any pain. He thought he was going to sleep. Then, "all of a sudden," he said, "I found myself walking on a good road. I followed this [ghost road]. On it I came to a wigwam. I saw an old man there. He spoke to me. 'Where are you going?' he asked me. I told him, 'I'm going this way.' 'You better stop and have something to eat,' he said. I told him I was not hungry, and started off again. He came along with me. 'I'll show you where your parents are staying,' he said. While we were walking we came in sight of lots of wigwams [a]s far as I could see. ... The old man pointed one of them out to me. 'You go there,' he said, 'that's where your mother and father live.'

"So I went there. I found my father in the wigwam. He shook hands with me and kissed me. My mother was not there. Soon she came in, and greeted me in the same way. My father called out, 'Our son is here!' After that a lot of people came in to see me. They asked about people on this earth. They wanted to know whether their friends were well. I told them that they were not sick. Then I was offered something to eat. But I could not eat. Some of these people that came to visit me had moss growing on their foreheads, they died so long ago.

"While I was talking, I heard three or four beats of a drumstick. They were very faint, I just barely heard them, they were so far away. All of a sudden I thought about coming back. I thought of my children I had left behind. I went outside the wigwam without telling my parents. I started back along the same road I had followed before. When I came to the old man's wigwam he was not there. I kept on walking along the road. Then I thought I heard someone calling me. I could hardly hear the voice and I could not recognize who it was. Finally the voice became plainer. I knew that I was getting nearer then. When I got still closer, I could hear my wife and children crying. Then I lost my senses. I could not hear anything anymore.

"When I opened my eyes and came to my senses it was daylight. But even daylight here is not so bright as it is in the country I had visited. I had been lying for two days. But I had traveled a long distance in that length of time. It is not right to cry too much for our friends, because they are in a good place. They are well off there. So 
I'm going to tell everybody not to be scared about dying." (Hallowell, $1967 / 1940$, pp. 152-3)

The second narrative came from a man named Caúwanäs (One Who Travels with the South Wind), who was so ill he was expected to die. When he recovered, he told his nephew: "I got pretty close to [the spirit/ghost land]. I was on the road there" (Hallowell, 1967/1940, p. 153). He said that he saw lots of strawberries along the way to that place, including one so gigantic passersby had scooped out parts of it to eat just on the border of a town. As he approached the town, he could hear laugher and shouting, but someone met him on the road and ordered him back, saying he was not yet ready. He had gotten close enough to the town, though, to recognize one person he knew, a man of the Poplar River Band who had quite a reputation among the Saulteaux because he had once eaten human flesh.

\section{Black Elk's Two NDEs}

The famous oral history of Black Elk, an Oglala Sioux shaman (1863-1950) who survived the battle with Custer and the massacre at Wounded Knee, was recorded in 1930 by John Neihardt. Neihardt was a poet, not an anthropologist, and there has been considerable debate about how much of the account was Black Elk's voice and how much was Neihardt's. Neihardt's Black Elk Speaks (1988/1932) has become so widely known and has had such appeal that it has been taken virtually as a canon of Native American beliefs, though in fact it not only represents a particular tribe's culture but also reflects the rather unusual Messianic orientation of the last remaining Sioux, who were reduced to a remnant while their surroundings were rapidly moving into the industrialized $20^{\text {th }}$ century. Black Elk's story contains two accounts of otherwordly journeys when he was seriously ill.

The first occurred when Black Elk was only 9, and is widely regarded retrospectively as his shamanic initiation (Neihardt, 1988/ 1932, pp. 20-47). It is impossible to give anything but the briefest overview of that experience here, but it was so sweeping in scope that it was immortalized in Neihardt's account as "The Great Vision." He became very ill, and lay as though dead for 12 days. While he was in that state, Black Elk was guided to the Grandfathers he was told were calling him, and he found himself flying through the air toward a celestial realm that resembled a radiant, beautiful Earth. There he 
saw visions of plenteous herds of magnificent animals before going to the Grandfathers' council, which he realized was actually a convocation of all the cosmic forces personified. In turn, each of the Grandfathers gave him supernatural powers, insight, and prophetic visions. He saw heavenly visions of his people prospering and happy, and although he perceived many threats and hard times ahead, the tone of his vision was one of Messianic hope, in that he seemed to be given magical powers that would assuage the hardships threatening his people. In several scenes, Black Elk responded to challenges correctly, so that the Grandfathers later said he had "triumphed" and they brought him back to earth (Neihardt, 1988/1932, p. 44). It was obvious to some members of his tribe that Black Elk had changed as a result of his experience. He appeared to some to be filled with radiant light (Neihardt, 1988/1932, p. 49).

Many years later, after the Sioux had been defeated, Black Elk performed in Buffalo Bill's Wild West Show in London for two years, until he began to sicken and long for home (Neihardt, 1988/1932, pp. 224-5). The show moved on to Paris, but he was too ill to participate. One morning, as he was sitting down to breakfast with his girlfriend and her family, the ceiling and the room started spinning, and Black Elk was again swept into a vision. According to his breakfast companions, he had looked up, smiled, and then fallen "dead out of [his] chair," remaining comatose for three days (Neihardt, 1988/1932, p. 228). As for Black Elk, he was being carried high above the ground on a cloud high above the Earth that took him from Europe to a place above the Missouri River and the Black Hills and the "center of the world where the spirits had taken [him] in [his] great vision" (Neihardt, 1988/1932, p. 226).

The cloud finally stopped over an enormous encampment of all the Sioux bands, where he could see his parents' teepee. Black Elk wanted to join them, but he feared jumping down from such a height would kill him. His mother, who was outside cooking, seemed to look up and see him, but at that moment the cloud started moving rapidly away, carrying him over strange, industrialized landscapes into a blackness. Black Elk grieved because he wanted to be with his people, but soon he began to see light ahead and then "towns and green land and houses all flying backwards," as he was returned to the household where his body lay (Neihardt, 1988/1932, p. 227). Black Elk asked to go back to the United States, and although he was sick, he made passage almost immediately. He headed toward Pine Ridge to find his people: 
Everything was just as I had seen it from the cloud. All the Lakotas were there, as I had seen them, because that was the year of the treaty (1889) when the [whites] bought some more of our land ... I had been away nearly three years and knew nothing about this foolish thing until then.

My mother's tepee was right where I had seen it when I looked down from the cloud, and other people were camped exactly where I saw them.

My parents were in great joy to see me and my mother cried because she was so happy. I cried too. I was supposed to be a man now, but the tears came out anyway. My mother told me she had dreamed one night in her sleep that I had come back on a cloud, but could not stay. So I told her about my vision. (Neihardt, 1988/1932, p. 229)

\section{Profiling the Accounts}

What can be said about this handful of accounts spanning almost four centuries, most of a continent, and at least six different cultures? They share a number of features that are associated with the NDE markers common in industrialized countries and across multicultural studies. However, since these narratives were not gathered with the aid of today's protocols, certain areas of comparison are difficult to determine. For instance, it is impossible to infer from some of these accounts whether the experiencers felt a sense of well-being upon making the transition; only in the case of Palowahtiva is this explicit. Nor is there an explicit sense of having out-of-body experiences as they have been reported in the NDE literature.

Some well-known modern phenomena were not prominently featured in these narratives at all. Entering the darkness was hardly a universal experience, and the only transition remotely resembling a tunnel was the subterranean passage in Geronimo's account. No life reviews were reported. The illumination of the other world seemed qualitatively different from the lit-from-within jewel-like landscapes of contemporary NDE accounts, and neither the dead nor the gods, with the possible exception of some entities in Black Elk's Great Vision, were described in terms suggestive of the Beings of Light. None of the Native Americans described anything like seeing the Light, reported as a distinct phenomenon with a presence or intelligence noted in contemporary NDE accounts, and then going into the Light. Nevertheless, these accounts did cluster along certain groups of features common to other NDEs, in addition to features that seemed particular to them as a group. 
The following section discusses clusters of experience represented by the accounts. Frequencies are shown, but the material is grouped according to related phenomena to avoid redundancy and to connect certain themes.

\section{Crossing the Border into the Other World}

Although some contemporary NDE accounts read like a journey from one spatial location to another where a path appears for the experiencer's progress, such a structural unfolding is not the norm. Crossing from life to death in the Christian medieval stories gathered by Carol Zaleski (1987), however, seems to unfold in just such a way, and she described sometimes incredibly detailed landscapes negotiated by either a path of sorrow and pain or a pleasant one. The Native American accounts resembled medieval Christian ones in this regard.

Journeying along a Spirit Road: 6 Accounts. One of the most common elements in the accounts was the sense of traveling along a pathway in the spirit realm that led the deceased from his present location to a destination, which turned out to be the paradisiacal place where the dead dwelt. The means of locomotion was not specified, as though it was unremarkable, leading to the inference that it might usually have been walking, since horses and other significant animals were usually described. Only Palowahtiva and Black Elk made explicit reference to horses. The sense of the stories implied that the journey took several days. The four-day convention, which appeared in the Chippewa narratives, was a common one in a number of Native American traditions.

In three reports, the countryside surrounding the spirit path was Arcadian: beautiful, full of lush and wondrous plants and plentiful, fat, large game animals. The beauty of this sylvan landscape directly paralleled that of the pastoral scenes described in NDEs from other cultures (Lundahl and Widdison, 1997). Only in the Apache story was the pathway hazardous. Interestingly, in marked contrast to Native American beliefs as recorded in myths and folktales (Hallowell, 1967; Kalweit, 1988; Thompson, 1929), none of these NDEs, including the Apache report, featured the afterlife convention of a narrow, slippery bridge over a black river full of people who had not been able to make the passage that the dead must cross. However, in two accounts the direction of the path was indicated as westward, which did correspond 
to the common belief in Native American and many other cultures that the dead lived where the sun set.

Being Led by a Guide: 3 Accounts. Only a few individuals met psychopomps who were to serve as their guides to the spirit world, and there was no commonality among the guides other than their function. In contrast to the majority of contemporary records, only one psychopomp was a deceased relative, and, rather surprisingly, one whom the deceased did not recognize, and for that reason, hesitated to accompany: the unknown "grand-grand-uncle" in Palowahtiva's narrative. Flat-Stone was already on his way when he met a stranger who offered food and, when this was declined, his company and guidance for the journey. Black Elk was summoned by supernatural warriors he recognized from a previous vision (not a near-death experience) descending from the clouds, who told him the Grandfathers had summoned him.

Meeting Challenges: 4 Accounts. Like the medieval narratives with their pathway construction beset with ordeals (Zaleski, 1987), the Native American accounts featured obstacles on some of the paths. Of the narratives that contained challenges, three involved obstacles barring further progress along the path, and all represented barriers to the next stage of the journey, almost in the nature of ordeals. The most elaborate of the passage ordeals was the Apache account, in which the deceased immediately encountered what appeared to be a guard, posted to bar entrance to a natural passageway in the landscape; next an apparently insurmountable rock blocked the path; and then, the subterranean passage widened and narrowed, forcing the deceased to progress through a series of deadly animal pairs that threatened him, before finally having to negotiate the clashing stone walls of the passage. With the exception of the rock, which demanded ingenuity, agility, and courage to skirt, the correct response to the challenges was to confront them bravely by walking through or past them, as though they engendered no fear.

The two Chippewa narratives generally followed the same pattern, except that the obstacles took the form of supernatural fire that would move and flare up to block the path of the deceased, no matter which evasive maneuvers he took. In both cases, the deceased had to exert a tremendous force of will to overcome his natural reluctance to hurl himself through the towering wall of fire in front of him to reach his goal. A feature unique to these accounts, though, is that this obstacle was a bar not to further journeying in the spirit world, but to the land 
of the living. The fires in the Chippewa stories blocked the war-leader from re-entering the battlefield to reclaim his body after his frustrating attempts to exist without it, and they blocked Gitshee Gauzinee from re-entering his lodge to obtain his rifle, which he needed in the spirit world. The war-leader, whose spirit had not gone into the spirit world but remained in the here-and-now, wanted to return to the world, which only his body had left, but it appeared that Gitshee Gauzinee merely wanted to get his rifle and stay in the spirit world where he was. Both found that by crossing the fire, they had come back into their bodies in the realm of the living.

Black Elk's ordeals were quite different. His adventures in the spirit world did not involve a pathway so much as flying through the air, and instead of encountering obstacles to his way, he was instructed to undertake certain actions with some of the magic gifts he had been given, which he accomplished with ease, such as killing a supernatural being to restore harmony and plenty.

Interacting with the Living: 2 Accounts. The Chippewa war-leader and Black Elk were the only two individuals who seemed able to interact in the world of the living. The war-leader clearly experienced himself subjectively as having a normally functioning material body that was operating in the here-and-now, yet nobody else could see him. Although he was wounded, he managed to keep up with the others on the return journey, "walking when they walked, and running when they ran" (Schoolcraft, 1975/1825, p. 405), but the account made it clear that he suffered from hunger, thirst, his wounds, and the cold in attempting to keep pace with them. His interactions, try as he might, were ineffectual, and the most he could manage was to create soughing sounds when he shouted and a slight headache when he struck his wife a doughty blow. His experience of events seemed completely realistic, and the account implied, though it never stated explicitly, that the actions of the living he observed actually took place.

Black Elk, on the other hand, flew over a realistic landscape in a manner suggestive of airplane travel, an impossibility at the time of the events he related but extant by the time his narration was recorded, viewing the living from this great height; yet he was able to capture his mother's attention far below. According to Black Elk, when he was able return to the United States, the encampment was just as he had seen in his vision, including the location of his parents' teepee, and his mother corroborated that she had seen him in a dream. 
Going into Darkness: 3 Accounts. Darkness was not a prominent feature of these narratives, and nothing like a tunnel appeared, with the exception of the darkness around the subterranean passage beginning the Apache account and Palowahtiva's darkening vision, after the ancient Zuni ancestor turned to depart and he found himself in his sick body again. The only other period of darkness reported was one through which Black Elk had to pass when his traveling cloud took him "backwards" from his parents' village to his departure point in Europe, in a manner highly suggestive of an airplane passing through different time zones.

\section{The Happy Hunting Grounds}

The nature of the spirit world and the beings that inhabited it differed in their numbers more they did in kind from contemporary accounts. As noted above, some features did not appear, but of the ones that did, only superficial differences existed.

Light in the Spirit World: 5 Accounts. The radiant illumination of the spirit world appeared in over half the reports, though not in the pronounced way it does in contemporary accounts. Light was not said to glow from the natural features of the landscape, but to form a general brilliance that illuminated everything the way a celestial body does, though no source for the light was ever mentioned. Light from the spirit world might have entered the here-and-now, as it did in Palowahtiva's story, or lingered afterward inside the person, as it was said to in Black Elk.

Reaching Paradise: 5 Accounts. The destination at the end of the spirit road appeared to be the Native American equivalent of the celestial cities mentioned in EuroAmerican NDEs, blended with the elysian fields those accounts also mentioned. It was each culture's version of paradise, a splendid but recognizable place where the other spirit beings dwelt. In the First Nations records, it was a large clustering of dwellings, such as lodges, wigwams, or teepees, laid out in a familiar arrangement from the person's tradition. The accounts clearly suggested that these encampments were considerably larger and more populous than usual in life. These prosperous settlements were located in lush countryside, rich with vegetation and game, the "happy hunting grounds" of legend. The inhabitants appeared to be going about their usual activities, just as they did in the accounts from other cultures (Lundahl and Widdison, 1997). 
Seeing the Dead: 6 Accounts. Most narrators specifically mentioned seeing the dead, usually meeting predeceased relatives, especially parents, but often other individuals known to them or comparative strangers, such as the man who had a reputation for having once eaten human flesh in the second Saulteaux narrative, and the long-dead who had moss growing from their foreheads. These spirit beings were evidently easily recognizable so they must have closely resembled what they looked like in life. None was mentioned as glowing with light. In most cases there was a sense of joy in being reunited with loved ones and being among their people again, made more poignant in the later stories when the First Nations had been almost obliterated, such as the one Geronimo related, when the narrator's yearning to be back among the friends, family, and entire society since lost was piercing.

Finding Death Beatific: 5 Accounts. With the exception of the first narrative John Smith reported, in which the person was saved from going to the hell of Popogusso, the rest who glimpsed afterlife found it to be sublime. The dead lived in joy and plenty, a fact that impressed the deceased so much that some of them could hardly wait to tell others the good news so that they would not be afraid to die.

Meeting a God: 3 Accounts. Three persons met supernatural beings who were more like gods than humans. No detail was given for the god who saved the man from entering hell in the Smith account. In Palowahtiva's narrative, the extremely ancient man who authoritatively denied that his "god-like" grand-grand-uncle could take him seemed, by inference, through his human appearance, which included significant decrepitude, to have been an ancestral progenitor of the Zuni people from the primordial past of myth. Black Elk's Great Vision was full of supernatural beings, but the ones that clearly had the most power were the Six Grandfathers, whom he characterized as being the Spirit of each of the cardinal directions, the Spirit of the Sky, and the Spirit of the Earth.

\section{Returning to Life}

The return of these speakers to the land of the living occured under varying circumstances, just as it does in contemporary accounts, although no clear borderline appeared to block their progress into the spirit world. Instead, spirit beings turned them back, or they found themselves unintentionally drawn back by their own actions, or by the actions of others. Like many of the medieval experiencers (Zaleski, 
1987), some felt they now had a responsibility to tell others what had happened to them, while others felt they had a specific charge they must undertake.

Being Told to Return: 4 Accounts. People were told to return with varying degrees of forcefulness and varying rationales. In one of the Smith stories, the deceased was "given leave" to return (Smith, Book I, folio 11, in Barbour, 1986, p. 79), but was charged with a commission, which might have meant that the suggestion of permission was merely a polite phrasing for a command. In the second Smith story, the dead individual's mission was clearly the reason he had to return. Palowahtiva's return was disputed by the two spirit beings he met, but the ancestor-god made it clear that he was needed on earth, and that he would not be called to join the spirits until he was an old man. The reasoning was that he and others like him were needed on earth to support the spirit world. The Saulteaux One Who Travels with the South Wind was turned back on the roadway because it was not his time either, and Black Elk's traveling cloud snatched him away against his will and back to life.

Returning Unintentionally: 2 Accounts. Gitshee Gauzinee, who had only gone back to get his rifle, found, when he passed through the fire, that he was back in his body and among the living, though leaving the spirit world had not been his intent. In the Flat-Stone Saulteaux narrative, the beating of a drum interrupted the deceased's conversation with his parents, causing him to remember the world he had left behind, especially his children, summoning him back to life. He appeared to be drawn back along the pathway he had come by more and more sounds that gradually were discernable coming from the living, until he awoke to the laments of his wife and children.

Receiving a Commission: 4 Accounts. A significant number of people were charged with commissions to perform when they came back to life. Three of the four came from gods, while one, in the second Smith account, came from the man's deceased father. Both of the Smith commissions concerned injunctions to instruct people how to live well in order to enjoy the pleasures of the afterlife. Palowahtiva, on the other hand, was told, in effect, to "keep the faith" in terms of making the traditional prayers and observances to sustain the spirits in the other world and maintain the integrity of the Zuni religion among its dwindling numbers. Black Elk was given extraordinary powers and 
prophetic visions showing him that he had a special role to play to help his people survive extremely difficult times.

Creating a Commission: 3 Accounts. Some people were so moved by their experiences that they created their own missions to accomplish when they returned to the here-and-now. Both of the Chippewa stories involved insights about the afterlife from individuals who were focused on their bodily hardships after death, especially hunger. They determined to come back and share their experiences with the living, in order to alter funerary and burial customs that inconvenienced the dead, although in the first of these cases, the advice of building a fire on the grave seemed to have only a tangential relationship to the primary frustrations the deceased war-leader experienced in getting food, water, and medical treatment. In the Flat-Stone account, the experiencer was so delighted by what he had seen in the other world, he determined to spread the word on his own so that people would not sorrow too much for their loved ones or be afraid to die.

\section{Considering these Native-American Narratives as a Whole}

The group of published accounts most similar to these cases is Zaleski's medieval Christian study (1987), in which the majority of records featured a pathway organization through a structured landscape; two kinds of pathways, one beset with difficulties and another pleasant; a guide leading the individual through a series of ordeals which many did not pass, including fire; and a soteriological message that ultimately supported the religious conventions of the day. However, the Native American NDEs appeared to have the most in common with a single reported case of a Hawaiian woman recorded by Thomas Thrum in a 1907 book of traditional Hawaiian folktales and recounted recently by Allen Kellehear (2001).

The woman died, spent some time looking back at her body and comprehending her situation, and then began a journey, walking, as she supposed, along the path to the next village. Instead of finding the familiar hamlet she knew, she discovered an extremely large settlement thronged with thousands of people. She recognized some of them, but most were strangers to her, and the ones she knew were dead. She was amazed by how joyful they were. She went from that village to another, and another and another, where she found es- 
sentially the same thing, until, on her way to a volcano, a group of people told her she had to return to life.

This case, although it includes the out-of-body experience missing from Native American reports, clearly demonstrated the pathway progress to a large, paradisiacal settlement of the joyful dead. Like most of the Native American accounts, it also lacked a tunnel-like transitional element or passage through darkness, a life review, any report of personal euphoria, a different sense of body, beings of Light, and the Light as a presence or intelligence. The Hawaiian case was also interesting in that, even more than the later Native Americans who were largely treated as enemies and savages by the Europeans, the Hawaiian people had been subject to extreme religious pressure by Christian missionaries to abandon their traditional beliefs; yet the imagery in this account remained quite consistent with the bulk of the Native American ones. On the basis of this single case and the mere handful of Native American accounts, it is perhaps tenuous to speculate, but not tenuous to nullity. It may well be that indigenous people whose way of life was still largely uncontaminated by civilization had similar views of the afterlife.

The indigenous NDE literature is still a very small one. Where other accounts from indigenous people have been published, they showed a great deal more diversity in terms of their content, many having quite idiosyncratic elements as well as distinctly culture-bound features, such as the Kaliai Melanesian accounts reported by Dorothy Counts (1983), the Mapuche account described by Juan Gómez-Jeria (1993), the Chammorro accounts reported by Timothy Green (1984), and the Samoyed account described by Kalweit (1988). However, Counts, in the first and most thorough of these studies, observed that Kaliai NDEs lacked many of the features that contemporary researchers had attributed to NDEs, including the sense of being out of the body, euphoria, the tunnel, or a sense of having a different body (Counts, 1983, p. 131), all differences consistent with these Native American narratives.

Kellehear (1983), in a survey of nonWestern NDEs, included a number of indigenous accounts: the garbled Schorer version of the Chippewa stories mentioned above (1985), Counts's Melanesian study (1983), and isolated cases from an Australian Aborigine and a New Zealand Maori. He also concurred that indigenous cases lacked the life review and tunnel experience, though periods of darkness occurred in some accounts. Kellehear opined that the religions with written traditions divided the world into a material sphere and a spiritual one, 
whereas indigenous religions, and presumably others with oral traditions, did not sharply separate the two. He maintained that the religions with written traditions placed soteriological responsibility on the individual, making the person's past actions central to selfevaluation, hence making the life review significant. Extrapolating from Géza Róheim's psychoanalytic study of Australian Aborigines (1932), Kellehear maintained that in indigenous cultures, social sanctions were not internalized, so that indigenous people believed that they were fundamentally good and had no need for self-examination.

However, Kellehear's (1983) distinction did not hold for a significant proportion of Native American metaphysics. It was true that certain spirits inhabited the material world, but these tended to be the animate spirits of plants, animals, and natural forces. The dead lived in a spirit world that was quite separate, and some distance removed, from the material world. Clearly some of the accounts, including the earliest ones Smith gathered, included a sense of personal responsibility for actions. Whether the rationale was valid or not, Kellehear's and Counts's (1983) findings that the accounts of indigenous people tended to lack an out-of-body element and consistently lacked a tunnel, life review, and other body were supported by these Native American narratives.

Pursuing a related thread, it is worth turning a critical eye to the eleven Native American narratives as a group, albeit a very small one. Taken as a whole, there are four striking outliers from three sources: the Chippewa stories and Black Elk's experiences. Although these purported to be stories told by people who had survived death, their phenomenology and content were sufficiently different to suggest something different from the contemporary understanding of NDEs.

The first Chippewa story did not occur in the spirit world at all; rather, it was about paranormal events in the here-and-now, and it was ascribed not to a particular, historical person, but rather to a warleader described as a mighty hero felled at exactly the mythical moment when he turned the tide of a battle. There was more than a whiff of the legendary in that account, despite the fact that many cultures, including contemporary industrialized ones, have strong traditions that describe the spirits of the dead having just such difficulty interacting with the living. It is a theme mentioned in the out-of-body phase of contemporary NDEs, where the dead attempt vainly to secure the attention of rescue workers or grieving loved ones.

It also bore a strong resemblance to Tibetan delog accounts (Bailey, 2001). Delogs were persons who seemingly had been dead for several 
hours or days, but recovered spontaneously to tell detailed accounts of otherwordly journeys, usually emphasizing the teachings of Tibetan Buddhism. A standard feature of the delog accounts was a fairly long period of time and several adventures that occurred when the delog did not realize he or she was dead and continued to try to interact with the living. Bailey, drawing on the work of Françoise Pommaret (1989), raised the issue that the linguistic and cultural definition of death was different in Tibetan and other eastern cultures, and that delog accounts might not have referred to clinical death as understood in the West but to the "departing of the principle of consciousness from the bodily envelope" (Bailey, 2001, p. 153), a condition that looked like death but that could occur under other circumstances, such as the meditative state called nirodh (Goleman, 1988). Thus, the possibly legendary war-leader may have been describing events that conformed to folk expectations, especially since he realized, at one point in the narrative, that he himself had been told of such times when the spirit left the body; or he might have been having a delog-type experience that might have resembled, but not been the same as, an NDE.

Moving to the second Chippewa account, without laying the first completely aside, it was attributed to a named individual, Gitshee Gauzinee. However, he emerged from an extremely vague time horizon that might well have been the mythic, or at least quasilegendary, rather than the historical, past. Even the dating of the story around the time rifles had been introduced among these tribes was not particularly helpful, especially since such a detail served only as a narrative device that could have been served equally well by another precious object. The aim of this story seemed primarily instrumental, even though it contained more of the same elements as the other First Nations NDEs: a path-led journey into the spirit world and a vision of the paradisiacal settlement surrounded by fat game. Its purpose was to convince the Chippewa to alter their burial practices.

Both these stories, in marked contrast to the other Native American accounts, centered on the bodily needs of the individuals, and both were essentially didactic in nature, concerning both the justification and alteration of religious traditions associated with the dead. This hardly made them unique in the near-death literature, however, for by so doing, they appeared to fulfill the same purposes of the medieval Christian accounts in upholding, establishing, and transmitting certain religious conventions.

Black Elk's visions were something else entirely. Prior to his Great 
Vision, he had had a number of other auditory and visual hallucinations as a young boy, and some of this early imagery was repeated in his Great Vision (Neihardt, 1988/1932). Unlike the other NDErs in this sample, Black Elk did not walk but flew through the air, and rode supernatural horses and clouds; he met all the gods, and from them received supernatural powers, prophetic and archetypal visions of good and evil outcomes; he was charged with tasks in the other world and with commissions for this world. His visions accorded much more closely with the shamanic tradition than the near-death records, even though various individual NDE accounts contained some of these elements.

As I have already been mentioned, Black Elk grew up in a time of widespread Messianic and apocalyptic ghost dance visions among the few First Nations left as they were on the verge of extinction, and, not surprisingly, his early years were dominated by a desire to return to the former life his people had enjoyed before the coming of the Europeans. Furthermore, his second vision, as he clearly stated, came from a time of great homesickness, which may literally have been the foundation of the condition from which he was suffering, when he was exiled from the United States to perform in Europe. He certainly attributed his decline to this long and humiliating separation from his people (Neihardt, 1988/1932, p. 225). Thus, it was perhaps not surprising that he was transported to the place where his family and the rest of his people were.

Without suggesting that he was not seriously ill on both occasions, it may well have been that an individual with his paranormal gifts or sensitivities either was susceptible to imagery beyond that of most people near death, or that despite the fact that he was ill, he was, in fact, having some other kind of altered-state experience.

In the first instance, the simple but plausible explanation is that some people - those who become known as psychics, shamans, magi, prophets, and so on - have greater sensitivities and capabilities than most other people. Ernest Hartmann (1991), James Brown (1986), and Andrew Newberg, Eugene d'Aquili, and Vince Rause (2001) have suggested this, and it is, in a way, just another reflection of the imaginally-sensitive psyche that has been used to explain some people's predilection to altered states, including NDEs (Ring, 1992). Such a sensitivity and history of prior visions may indeed have predisposed Black Elk to have had unique NDEs with richer and more varied content than most. This may have been especially true given the context of his times. Kenneth Ring, describing the prophetic 
visions of some contemporary NDEs, concluded that they should be understood as "manifestations of a collective prophetic impulse that historically tends to arise during periods of cultural crisis" $(1988$, p. 4), citing in support of this argument John Weir Perry's The Heart of History (1987), which specifically discussed the Messianic movement among Native Americans during the period in question.

In the second instance, it might be possible that Black Elk, regardless of his illness, actually did not have an NDE but instead went into another state, perhaps resembling the withdrawal of consciousness from the body described in many Eastern traditions that looks like death, such as is experienced by the Tibetan delogs (Bailey, 2001; Pommaret, 1989) and in the meditative state of nirodh (Goleman, 1988). It has become a popular supposition in contemporary shamanic studies that many involuntary initiatory events were NDEs, but there is no compelling evidence to suggest that this has been the case, especially since there is a vast variety of other altered states that may leave the body motionless and with an extremely low metabolism for extended periods of time.

In conclusion, it is impossible to determine whether these outliers represented NDEs according to contemporary definitions, other deathrelated altered states, or something else. But is worth noting the ways in which they differed from the other accounts in this sample, as well as the majority of other NDEs collected crossculturally and from other old sources. Even though this paper presents only a small sample of allegedly historical Native American near-death stories, one of the most striking things about these narratives that speak across the myriad cultures and centuries was that, as in contemporary and even the medieval NDEs, the narrators never quite found the afterlife to be what they expected, and for the most part, they were amazed at the beauty and richness of the afterlife, particularly the pervasive joy of those who live in the spirit world.

\section{References}

Bailey, L. W. (2001). A "little death": The near-death experience and Tibetan delogs. Journal of Near-Death Studies 19, 139-160.

Barbour, P. L. (ed.). (1983). The complete works of Captain John Smith (1580-1631) in three volumes. Vol. II: The generall historie of Virginia, the Somer Isles, and New England with the names of the adventurers and their adventures. Chapel Hill, NC: University of North Carolina Press. (Original work published 1623.) 
Barrett, S. M. (ed.). (1970). Geronimo: His own story. New York, NY: Dutton. (Original work published in New York by Duffield in 1906.)

Benedict, R. (1934). Patterns of culture. Boston, MA: Houghton Mifflin.

Brown, J. A. (1986). Relationships between phenomena of consciousness and interhemispheric brainwave patterns during nonordinary states of consciousness. Unpublished doctoral dissertation, Saybrook Institute, San Francisco, CA.

Counts, D. A. (1983). Near-death and out-of-body experiences in a Melanesian society. Anabiosis: The Journal of Near-Death Studies, 3, 115-136.

Goleman, D. (1988). The meditative mind: The varieties of meditative experience. Los Angeles, CA: Tarcher.

Gómez-Jeria, J. S. (1993). A near-death experience among the Mapuche people. Journal of Near-Death Studies, 11, 219-222.

Green, J. T. (1998). Near-death experiences, shamanism, and the scientific method. Journal of Near-Death Studies, 16, 205-232.

Green, J. T. (2001). The near-death experience as a shamanic initiation: A case study. Journal of Near-Death Studies, 19, 209-226.

Green, J. T. (1984). Near-death experiences in a Chammorro culture. Vital Signs, 4(1-2), 6-7.

Hallowell, A. I. (1967). Spirits of the dead in Salteaux life and thought. In Culture and experience (pp. 151-171). New York, NY: Shocken. (Originally published in 1940 in the Journal of the Royal Anthropological Institute, LXX, 29-51.)

Hartmann, E. (1991). Boundaries in the mind: A new psychology of personality difference. New York, NY: Basic Books.

Hultkrantz, $\AA$. (1987). Native religions of North America: The power of visions and fertility. San Francisco, CA: Harper and Row.

Kalweit, H. (1988). Dreamtime and inner space: The world of the shaman (W. Wunsche, trans.). Boston, MA: Shambhala.

Kellehear, A. (1983). Culture, biology, and the near-death experience. Journal of Nervous and Mental Disease, 181, 148-156.

Kellehear, A. (2001). An Hawaiian near-death experience. Journal of Near-Death Studies 20, 31-36.

Lundahl, C. R., and Widdison, H. A. (1997). The eternal journey: How near-death experiences illuminate our earthly lives. New York, NY: Warner.

Moody, R. (1975). Life after life. Covington, GA: Mockingbird Books.

Neihardt, J. G. (1988). Black Elk speaks: Being the life story of a holy man of the Oglala Sioux. Lincoln, NE: University of Nebraska Press. (Original work published 1932.)

Newberg, A., d'Aquili, E., and Rause, V. (2001). Why God won't go away: Brain science and the biology of belief. New York, NY: Ballantine.

Perry, J. W. (1987). The heart of history: Individuality in evolution. Albany, NY: State University of New York Press.

Pommaret, F. (1989). Les revenants de l'au-delá dans le monde Tibétain: Sources littéraires et tradition vivante [Those who return from the hereafter in the Tibetan world: Literary sources and living tradition]. Paris: Editions du Centre National de le Recherche Scientifique.

Ring, K. (1988). Prophetic visions in 1988: A critical reappraisal. Journal of Near-Death Studies, 7, 4-18.

Ring, K. (1992). The omega project: Near-death experiences, UFO encounters, and mind at large. New York, NY: Morrow.

Róheim, G. (1932). Psychoanalysis of primitive cultural types. International Journal of Psychoanalysis, 13, 1-224.

Sabom, M. (1982). Recollections of death: A medical perspective. New York, NY: Harper and Row.

Schoolcraft, H. R. (1975). Travels in the central portions of the Mississippi Valley: 
Comprising observations on its mineral geography, internal resources, and aboriginal populations. Millwood, NY: Kraus Reprint. (Original work published 1825.)

Schorer, C. E. (1985). Two Native American near-death experiences. Omega, 16, 111113.

Thompson, S. (1929). Tales of the North American Indians. Cambridge, MA: Harvard University Press.

Thrum, T. G. (1907). Hawaiian folk tales: A collection of native legends. Chicago, IL: McClurg.

Zaleski, C. (1987). Otherworld journeys: Accounts of near-death experience in medieval and modern times. New York, NY: Oxford University Press. 